地 震

第 2 輯

第 61 巻特集号（2009） S509-S517 頁

\section{歴史地震史料の 全文データベース化}

石橋克彦 ${ }^{\dagger}$

\section{Full-text Databasing of Historical Earthquake Documents}

\author{
Katsuhiko IsHIBASHI \\ 2-28-26 Yokowo, Suma-ku, Kobe 654-0131, Japan
}

(Received October 24, 2008; Accepted January 12, 2009)

Almost all of Japan's known historical earthquake records since around the 6th century, which are clippings from various historical sources, have been published in typeprinted books of 31 volumes. They are invaluable primary data for the Japanese historical seismology, although buried historical materials should further be searched for and added. There are, however, two serious problems in these books. One is that they contain rather many unreliable materials because the compilers did not carry out any critical examination of historical sources nor selection, which tends to produce errors in historical earthquake study. The other is that the books are just a huge amount of printed papers, which makes full-scale utilization of massive information including keyword searching impossible. In order to improve these situations fundamentally, it is very important to construct a full-text digital database of all historical earthquake documents after critically examining them, carefully emending every text, and composing a re-edited collection in digital form. Recently, such a database, Online Database of Historical Documents on Japanese Earthquakes and Eruptions in the Ancient and Medieval Ages, has been established through an interdisciplinary collaboration among earth scientists, historians and information scientists under the Grants-in-Aid for Scientific Research by MEXT (Ministry of Education, Culture, Sports, Science and Technology). Although its period is restricted for the ancient and medieval ages (up to ca. A.D. 1600), it will be able to be expanded to the early modern age because its basic design is systematic and solid. However, the construction of a reliable full-text database of historical documents on the Japanese early modern earthquakes is considered to require a longterm and wide-scale national project because the amount of documents to be examined and processed is extremely huge.

Key words: Historical seismology, Historical earthquake documents, Full-text database, Japan

\footnotetext{
${ }^{\dagger}$ ○654-0131 神戸市須磨区横尾 2-28-26
}

§1.はじめに

近代科学的な器械観測にもとづく地震研究の歴史は たかだか 100 年余に過ぎないから，それ以前の古い地震 の調査・研究が地震学にとって必要不可欠であることは 論をまたない.

器械観測以前の地震 (pre-instrumental earthquake) を 総称して古地震 (paleoearthquake) というが, 古地震学 (paleoseismology) は近年めざましく発展して, 各地域の 長期的な地震活動史や地震発生予測ばかりではなく, 大 地震のくり返し性, 地震テクトニクス, 震源破壊過程な ぞの一般論の研究にも大きく貢献している. 古地震学と いうと狭義には地形・地質学的手法による研究を意味す ることが多いが，文字記録 (文献史料) にもどづく歴史 地震学 (historical seismology) も, 歴史時代の長い日本で は, 過去の地震活動と地震現象, 地震災害, 地震と社会 ・ 人間の係わりを詳しく知るという点で, きわめて重要な 役割を演じてきた。

歴史地震学は歴史時代の地震の観測・調査・研究とい えるが, 観測データに相当する地震史料 (文書・記録・ 典籍などに記された地震記事，絵図・地図なども含む） の収集・整備が, 基盤観測という意味で基本である。こ れに関しては, 長年, 地震史料の収集という, いわば観 測データ取得の面ばかりが強調されてきたきらいがある が, データの保管と流通・共有 (活用利便性) を高度化 することが非常に重要になってきている.

宇佐美 (2003) の歴史地震カタログなどを見て，日本 の歴史地震研究はほぼ完了したと思っている人がいるよ うだが, $20 \sim 50$ 年弱の現代的地震観測の 20 倍以上の 長期間の地震観測データは, 最新の地震学の知見に照ら して絶えず見直すことによって新たな発見をもたらす可 能性を秘めており, 多くの地震研究者が容易に使えるよ うになっていなければいけない,さらに震災軽減という 観点でみると, 地震史料は, 参考にするべき膨大な情報 や教訓を蔵している。

その意味で地震史料のデータベース化が日本の地震 科学の基盤整備の重要課題の一つと考えられるのだが, 阪神・淡路大震災以後の地震調査研究推進本部体制のも とでも忘れ去られてきた。 そこで本稿では, この問題に 絞って現状と問題点を述べる. なお, 日本の歴史地震研 究のまとめや問題については, 石橋 $(1987,1995)$, 小山 (1999), Ishibashi (2004) などを参照されたい.

\section{$\S 2$. 地震史料集と問題点}

日本では, 明治初年に近代地震学が誕生したときか ら, 地震の摇れを器械 (地震計) で正確に観測して数理 的な地震研究をおこなうことと並んで, 日本列島の歴 
史地震研究が重視され, その基礎となる地震史料の収 集に努力が注がれた [例えば, 宇佐美 (1995), Ishibashi (2004)）。 その最初の集大成として, 明治 37 (1904) 年 に田山実の編纂による『大日本地震史料』 2 冊（震災予 防調査会報告, 第 46 号 (甲), 606 pp., 第 46 号 (乙), 595 pp. ; 本稿では田山史料と略称) が刊行された。これは, 465 点の古記録・古典籍・古文書より, 允恭天皇五年か ら慶応元 (1865) 年二月までの大小 2 千余の地震の記事 を抜き出して, 編年順に原文を活字で掲載したものであ る. 津波は当然これに含まれるが, 火山噴火についても 同様の努力が払われ, 大正 7 (1918) 年に大森房吉編纂の 『日本噴火志』 2 冊（震災予防調査会報告, 第 86 号, 236 pp., 第 87 号, 116 pp.) (復刻版 : 有明書房, 1991) が刊行 された。

昭和 $16 〜 18$ (1941〜 43) 年には, 戦時中の困難な状 況のなかで, 武者金吉の編纂による『増訂大日本地震史 料』3 冊 (文部省震災予防評議会, 第一巻, 945 pp., 第二 巻, 754 pp., 第三巻, 945 pp.) (復刻版 : 鳴鳳社, 1975 76) が謄写印刷で刊行された。これは, 武者が約 13 年に わたってほとんど独力で田山と大森の書物を増補改訂し たもので (弘化四年末 1848 年 1 月 / まで), 郷土誌や口 碑・伝承や外国人の記録，地震・噴火に関係すると思わ れる諸現象の記事, 台湾・朝鮮の記録も収録された。慶 応三 (1867) 年までの第四巻の原稿は戦火を避けて土中 に埋められていたが, 昭和 26 (1951) 年に武者金吉『日 本地震史料』（毎日新聞社， 757 pp.)（復刻版：明石書店, 1995）として出版された（これら４冊を本稿では武者 史料と略称). 収載するイベントの数は, 田山史料より 6500 近くも増えた。

武者史料のあと地震史料の収集 ・刊行は長く途絶え ていたが, 1970 年代から宇佐美龍夫が中心となって全 国にわたる収集が開始された [宇佐美 (1995)]。とくに 近世の地方文書 (じかたもんじょ ; 江戸時代の農村の古 文書) や藩政史料が膨大に増強され，その成果は 1981 94 年に東京大学地震研究所 (編)『新収日本地震史料』 21 冊 (日本電気協会, 全 16,812 pp. ; 本稿では新収史料と略 称）として出版された。宇佐美はさらに精力的に収集を 続けており，1998～2008 年に『「日本の歴史地震史料」 拾遺』6冊（計 4,828 pp. ; 本稿では史料拾遺と略称）を編 纂・刊行している.

Photo 1 に, 武者史料に含まれる田山史料を除いて, す べての既刊地震史料集 31 冊の外観を示す (宇佐美によ る武者史料と新収史料の正誤表 1 冊も加えた)。これら の厚さは約 1.5 メートルに達する. 全国にはまだ多くの 地震史料が埋もれているだろうが, 現在知られている限 りのものは大部分これらの中に活字化されていると考え
られ，きわめて貴重な史料集である。これらを用いて， 宇佐美 (2003) の中の歴史地震カタログをはじめとして， 地震学, 災害科学, 歴史学の分野で多くの研究成果が生 み出されてきた。

しかし，前節で述べたように今後いっそう新たな目で 読み込まれる必要があるにもかかわらず，これら既刊地 震史料集は二つの根本的な問題をかかえている.

第一は, データそのもの (地震史料) の信頼性の問題 である. 玉石混淆の史料が素性・性格の吟味なしにすべ て同列に収載され，なかには史料とは呼べないような三 次的な文献（明治以降の市町村誌や最近の報告書など） もあり, かつ本文校訂が不十分なために, 間違っていた り信用できなかったりする地震記事がかなり混じってい る.それらにもとづいて誤った綱文 (それぞれの出来事 の簡潔な要約) が立てられ, すべてを鵜吞みにする利用 者（綱文を史実だと思っている人も少なくない）が的外 れな結論を導く原因になっている. 既存の歴史地震力 タログにも, そのような間違い (二セ地震 fake earthquake など）が含まれている。史料の信頼性を注意深く吟味す ると歴史地震像が変わってくる実例は石橋 $(1983,1997$, 1998), 山本・萩原 (1995), 山本・他 (1989) なぞに見ら れるが，それらは一部にすぎない.

第二の問題は, 十分な利用が物理的に困難な点であ る. 膨大な印刷物だけであるために, キーワード検索な どは不可能といってょく, 新しい着想を過去の事実で検 証したいなどと考えても, 多くの場合, パラパラと紙を めくって立ち尽くすしかない. すなわち, 地震学の進歩 に応じてくり返し縦横に読み返すという活用を, 史料集 自体が拒絶してしまっている.

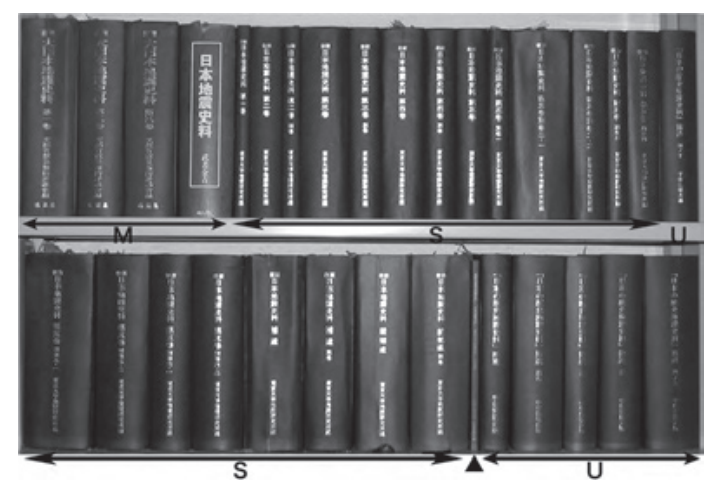

Photo 1. All the 31 volumes of the collections of historical documents on Japanese historical earthquakes and a correction booklet. M, Musha Shiryo; S, Shinshu Shiryo; U, Shiryo Shu-i. Solid triangle denotes a correction booklet for $\mathrm{M}$ and $\mathrm{S}$ prepared by Usami. 


\section{§3. 地震史料データベース化の歴史}

石橋（1985）は, 武者史料の中の問題史料の実例を幾 つか挙げ, 歴史学と地震科学の最新の成果を動員して史 料の校訂をすることを考えてもよいのではないかと指摘 した、そして、「このようなことに手をつけ始めれば，い ずれは, 日本語処理のコンピュータ・システムによる地 震史料データベースの構築という（たぶん国家的な）事 業にまで話は発展しそうである」と述べた。このように, 地震史料データベース化と, その前提としての電子化 は, 玉石混淆の既存史料集の校訂・精選という問題意識 と不可分であったことに注意したい，信頼性の高い地震 史料集を膨大な既刊のものから作ることは，紙ベースで は到底不可能と考えられたのである。

さらに石橋 (1987) は, 地震予知研究に抢ける歴史地 震研究をレビューしたなかで, 歴史研究者も正規のス タッフとして含むような歴史地震研究拠点の創設と並ん で, パソコンを用いCD-ROM を媒体とした既刊地震史 料集の全文データベース化を提案した[石橋 (1995) も 参照．それを試行するために 1987 年 3 月に科学技術 振興調整費「マグニチュード 7 級の内陸地震の予知に関 する研究」に建設省建築研究所から「地震史料のデータ ベース化とそれにもとづく歴史地震の震源断層モデルの 研究」という課題を申請したのは通らなかったが，デー タベース化の提案は関係者のかなりの関心と賛同を得 た.

1987 年 9 月に国立防災科学技術センター (現在の(独) 防災科学技術研究所）によって地震史料データベース化 プロジェクトが企画された [岩崎 $(1988,1999)] .11$ 月 には筆者らも交えた歴史地震史料データベース化委員 会が作られ, 1988 年 2 月には, 歴史地震研究会の一環 として「歴史地震史料のデータベース化に関する討論 会」が開催された [歴史地震研究会 (1988)]。これらの 検討にもとづき, 武者史料・第 1 巻と新収史料・第 2 巻 の 1596 年 9 月 5 日〜 1657/58 年の記事が全文データ化 され, 検索ソフトも作られて, 地震学会でも発表された [歴史地震史料データベース化委員会 (1989a, b), 岩崎・ 他 (1990)]. このデータベースは PC98 シリーズのパソ コンで動くもので, テキストは種々のインデックスを付 して外注で入力され, 表示・検索用のプログラムは吉井 敏剋が DOS-BASIC で作成したものを基にしていた。 し かし，入力を外注する予算が続かなかったことや，岩崎 伸一 (2008 年 11 月 6 日に 55 歳で逝去) の個人的努力に 負う面が強かったことなどから，プロジェクトは中断し て, 発展と普及には至らなかった。

その後, 地震・津波・火山噴火の史料の一部分や, 一 部期間について, 研究者個人やグループがデータベー
スを作成した例は幾つかあった[例えば, 茅野一郎（私 信), 松浦・他 (2003)]. 現在も, 独自に史料データベー スを整備しているグループはあるかもしれない.しかし， 一般公開を企図した組織的な動きは途絶えて, 日本語情 報処理技術が飛躍的に発展し, 歴史学や国文学の分野で 大掛かりなデータベース構築が進んでいるなかで, 地震 史料データベース化は著しく遅れていた。

なお，従来のデータベース化の議論では，ぞちらかと いうと, 既刊地震史料集という根本データ集の使い勝手 が悪く, しかも入手困難である点が強調されがちだっ た。それはもちろん重要な要因だが, 本節のはじめに述 べたように, 石橋 $(1987,1995)$ は既刊史料集の内容改善 に向けての不可欠なステップという面も重視して抢り， その意味では，データベース化に扔いて歴史研究者との 共同作業が必須という点が重要である.

\section{§4. 古代中世地震噴火史料データベース}

時間的・空間的にある程度広い範囲の歴史地震を対 象として, 公開を目的として組織的に地震史料全文デー タベースを作ったのは, 標記のもの [石橋 $(2005 a, b)$, 石 橋 • 他 (2003, 2005, 2008), Ishibashi et al. (2005, 2007)] だけであろう。これは，収録期間が古代・中世に限定さ れているが，基本的な方針や手法がしっかりした現代的 なデータベースであり, 今後地震研究の基盤として地震 史料データベースを整備していくうえで基礎となりうる ものだと思われる。そこで本節ではこれを概観する。

\section{1 データベースの概要}

「古代中世地震噴火史料データベース」(Online Database of Historical Documents on Japanese Earthquakes and Eruptions in the Ancient and Medieval Ages）と名付けら れたこのデータベースは, 日本の古代・中世の地震と噴 火抢よび関連事象に関する既刊の文献史料のすべてにつ いて, 史料学的・理学的検討を加えた結果を収録し, 検 索の便に供するものである。これは, 文部科学省科学研 究費補助金による二つの研究課題, 2003-05 年度・基盤 研究 (A)（複合新領域分野, 社会・安全システム分科, 細 目は自然災害科学, 課題番号 15201040)「古代・中世の 全地震史料の校訂・電子化々国際標準震度データベース 構築に関する研究」と 2006-07 年度・基盤研究 (B) (同 前, 課題番号 18310124)「古代・中世の地震史料の校訂 データベース化と共有型拡張・活用システムの開発」の 成果である. 第一の研究課題の申請に至った背景などは 石橋 (2005b) に述べられている. 第二の研究課題は, 前 年度申請制度による第一課題の継続である。メンバーは 以下の 14 名であった：石橋克彦 (研究代表者/神戸大 学都市安全研究センター/地震学・史料地震学), 小山 
真人 (静岡大学教育学部 / 火山学・史料地震火山学), 佐 竹健治 (産業技術総合研究所活断層研究センター／東京 大学地震研究所 / 地震学・古地震学), 都司嘉宣 (東京大 学地震研究所 / 海洋物理学・歴史地震学), 早川由紀夫 (群馬大学教育学部 / 火山学・史料火山学), 榎原雅治 (東 京大学史料編纂所 /日本中世史), 笹本正治 (信州大学人 文学部 /日本中・近世史), 高橋昌明 (神戸大学文学部 $/$ 同大学院人文学研究科 /日本古代 -中世史), 田良島哲 (東京国立博物館事業部情報課 /日本中世史・史料学), 藤田明良 (天理大学国際文化学部 /日本中世史・東アジ ア交流史), 矢田俊文 (新潟大学人文社会・教育科学系／ 日本中世史), 原正一郎 (国文学研究資料館複合領域研究 系 /京都大学地域研究統合情報センター／情報工学・地 域情報学・国文学情報処理), 安永尚志 (2005 年度まで /国文学研究資料館複合領域研究系/情報工学・情報文 学), 前嶋美紀 (研究協力者／まえちゃんねっと／システ ムエンジニア).

データベース作成の基本方針は, 日本の歴史地震研究 の根本資料となってきた武者史料と, その追補といえる 新収史料・史料拾遺の古代・中世部分の記事を, 校訂し てデータベース化することであった。 したがって, 武者 史料が収録している火山噴火および地震・噴火に関係が ありそうな諸現象 (降灰降砂, 日月色異常, 鳴動鳴響, 山 崩れ, 隆起陥没, 池水湧泉異常, 潮汐異常など）もすべて 含むことになった。ただし，噴火を含むこれら諸現象に 関しては，新収史料と史料拾遺は除外しているので，本 データベースは古代・中世の既知の記録を網羅してい るとはいえない. また, 武者史料は台湾と朝鮮の記録も 採録しているが, 本データベースは日本国内の出来事に 限っている．新たな地震史料を積極的に収集することは しなかったが, 作業の過程で気が付いた新史料は補充し た. 収録期間は, 便宜上, 近世初期の 1607 年 2 月（慶長 十二年一月）までとしている.

このデータベースの特徴は，(1) インターネットを介 してユーザの環境に関係なく汎用ブラウザで閲覧・検索 できるオンライン・データベースであること，(2) 古代・ 中世を専門とする第一線の歴史研究者たちが史料の校訂 をおこなったために内容が大幅に改善されて信頼性が高 まったこと，(3) データの作成に後述の XML (Extensible Markup Language）を採用したこと，(4) インターネット を介して関係者がデータを更新できる機能を備えている こと,である.

武者史料等は, 和暦発生年月日（+西暦発生年月日）・ 綱文・複数の史料 (史料名と史料本文) を 1 単位として, それらを年月日順に並べた編年史料集である。実は，田 山史料以来の地震史料集のこのスタイルは，日本史の基
本史料集である『大日本史料』に倣ったもので [Ishibashi (2004), 石橋 $(2005 \mathrm{a}, \mathrm{b})]$, 日本史関係の様々な史料集の 標準的なスタイルである. したがって，それを全文デー タベース化したことは, 今後, 地震学以外の多方面にも 大いに参考になることだと思われる。

期間を古代・中世に限定した理由は, 近世の地震史料 は極度に多量で, しかも地方史料や藩政史料が多く, 史 料批判を含むデータの整備に莫大な時間と労力がかかる からである. それに対して古代・中世の地震史料は, 小 グループがデータベース化の方法論と手法を短期間に開 発・確立して, 完結した具体的成果物を示すのに打って つけだと考えられた。 また, 最近, 活断層等から発する 大地震の長期予測のなかで古代・中世の地震が参照され ることが多くなったが, 少ない地震史料を史料批判なし に解釈している例が多く, 地震史料と地震像の信頼性を 高める実際的意味も大きいと考えた。近世の地震史料の データベース化ももちろん非常に重要だが, それは後述 のように, 大きなプロジェクトで事業的におこなうべき だろう。

\section{2 地震史料集の電子化と校訂}

まず, 紙版の地震史料集を電子化しながら校訂と編集 をおこない, データベースの基盤が用意された。

データ作成には XML (Extensible Markup Language) を 用いた $[$ 原 (2005) ]. これは, 文書の論理構造や体裁を タグ (識別子) によって指定（マークアップ）し，テキス トファイルに記述するマークアップ言語である。これ によって, 文字列だけでなく構造やレイアウトも含めた 文書を異なる情報システムの間で（とくにインターネッ トを介して）容易に共有でき，さまざまな出力を作り出 すことが簡単で, データベース化もしやすい. ウェブ (World Wide Web) で用いられている HTML (Hyper Text Markup Language）よりも高度なマークアップ機能をも ち, タグを自由に定義できるので, 史料本文にルビ・返 り点・割り注などが多いうえに校訂者の傍注や文末注を 付したりもする複雑な構造のデータの作成に打ってつけ であった。

XML データは, データベース化を念頭に置いた論 理構造を史料集の上に逐一カラーマーカで指示書きし （Fig. 1), 業者 (凸版印刷株式会社 / 情報・出版事業本部) に委託して, 武者史料・新収史料・史料拾遺の各巻ごと に作成した. 出来上がったものから MS Word ファイル を導出し, 縦書き印刷したものを歴史研究者が分担して 単純な入力ミスの校正をおこなうと同時に, 史料の校訂 と編集をおこなって業者に戻し, より高度な XML デー タにした。

史料の校訂は歴史学の研究レベルでおこなうのでは 


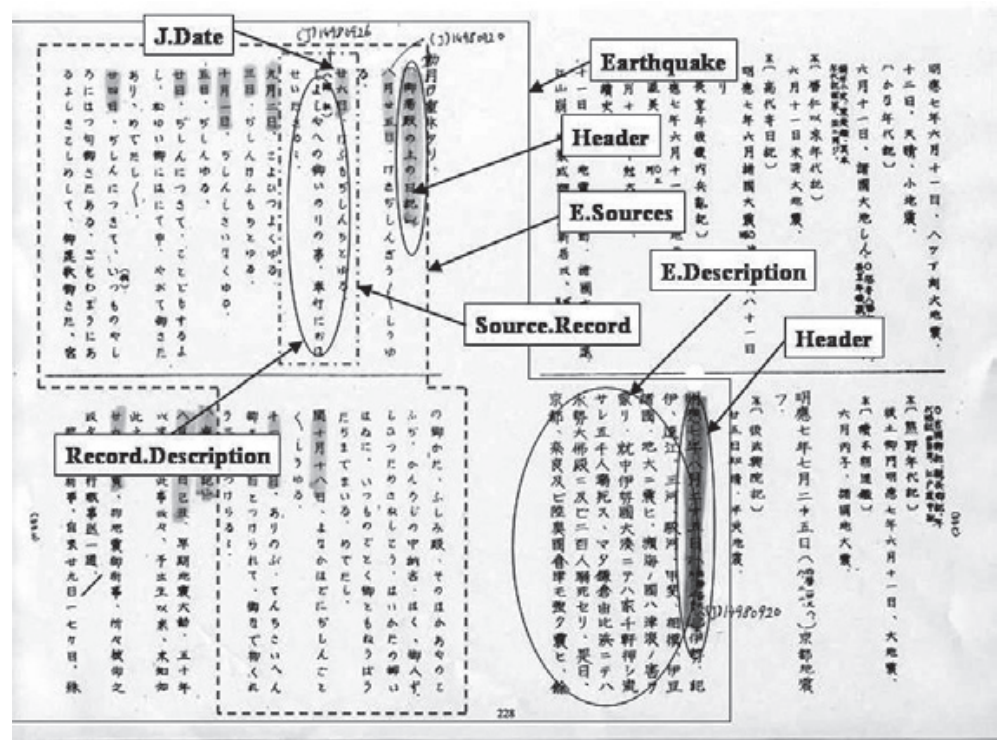

Fig. 1. An example of markup of historical documents for preparing XML data of the Online Database of Historical Documents on Japanese Earthquakes and Eruptions in the Ancient and Medieval Ages.

なく，地震研究者や防災関係者に良質の史料を提供する ことを主眼として, 信頼できる刊本がある場合にはそれ との照合を, ない場合には主として東京大学史料編纂所 所蔵の写本との照合をおこなうにとどめた。武者史料は 『続史愚抄』や『日本災異志』などの近世・近代の編纂物 から地震記事を採っている場合が多いが, 極力引用原典 に当たった．また，地震記事を含む部分たけを断片的に 収録しているために解釈を誤ることがあるので, 文脈を 読み取るうえで重要な記述が前後にある場合は, それも 採録するようにした。

この段階で, 史料の信頼性を評価する簡便な指標とし て, 史料ごとに史料等級を付記した。 それは概ね, A： 基本史料 (同時代の記録・文書, または古代・中世の編 纂物で根拠のある記録等にもとづいて作成されたと判断 されるもの), B : 参考史料 (江戸時代以前に作成された 記録・文書・典籍で, 適切な史料批判を経て活用できる と判断されるもの), $\mathrm{C}$ ：明治時代以降に作成・刊行され た文献 (一部に理学的な調査報告書等を含む), D : 史料 としては使えず削除すべきもの（史料の裏付けのない記 述のみの近・現代の書籍等; 新収史料以降はこれが多い), $\mathrm{E}$ : 保留史料 (研究期間内に信頼性を確認できなかった もの), である.ただし, これは史料本体について検討し たものであって, 記述内容を評価したものではない点に 注意を要する. 各史料名の後には, 史料本文の校訂に用 いた刊本等を示した.

校正・校訂作業は 3 回くり返し, その途中で, すべて
の史料集のデータをイベントごとに統合して, データ ベースの基礎となるXML データを完成させた.

\section{3 データベースの作成と内容}

データベースの仕様を研究グループで検討しつつ, 実 際の作成は業者（まえちゃんねっと）に委託した。デー タベース部には, フリーのリレーショナルデータベース 管理システムである PostgreSQL (ポストグレスキュー エル)，ユーザインターフェイス部には PHP 言語を用い ている [前嶋 (2004)]. 試作版では原史料の体裁に近い 縦書き表示もおこなったが, 公開版はすべて横書きであ る.

このデータベースでは, 個々の地震・噴火などを「事 象」と呼び,一つの事象に関する情報の集合を「事象レ コード」と呼ぶ. 各事象レコードは, 事象番号 (8 桁の数 字を基本とする固有の番号), 事象日 (和暦・ユリウス暦・ グレゴリオ暦), 事象等級 (史料等級が A と B の史料に もとづく事象が 1 , そうでない事象が 2), 事象種別 (地 震, 噴火, 鳴動, その他), 綱文, 史料数 (事象を記述した 史料の数), 史料群 (文献名十史料本文の群) から成って いる. 事象の概要を示す綱文は本研究で新たに執筆し, 武者史料とは異なる。事象レコードの総数は 3002 であ る.

データベースのトップ画面を Fig. 2 に示す (今後, 多 少の改変がありうる). 初めてアクセスしたユーザには 「構成と使い方」画面を読んでもらうことを想定してい る.「標準一覧表」画面 (閲覧・検索画面)に移ると, 初 


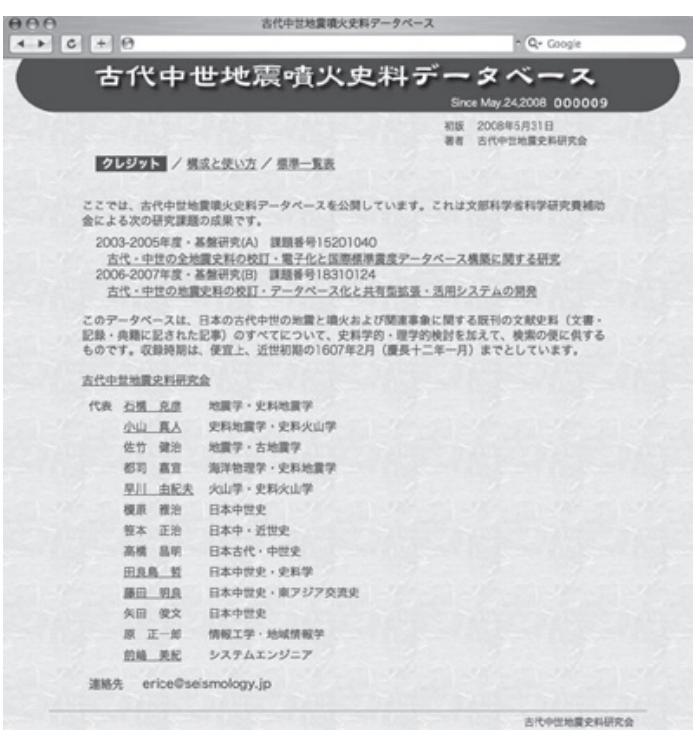

Fig. 2. Top page of the Online Database of Historical Documents on Japanese Earthquakes and Eruptions in the Ancient and Medieval Ages.

めての場合は後述の標準モードで，最古の 10 事象 (10 行）が表示されている（Fig. 3)。「一覧表示」のチェック ボックスやラジオボタンで選択したのち「表示更新」ボ タンを押すと, 希望する一覧表に変わる. 2 回目以降は, 前回終了時の一覧表が表示される。なお，綱文の表示文 字数の選択は，ユーザの画面サイズに適応するために用 意したものである。

一覧表には，標準モードとエキスパートモードの 2 種 類がある. 2 種類用意した理由は, 信頼性が低い史料の 記述やそれらのみにもとづく事象をユーザが事実だと思 い込んで利用するのを防ぐためと，そうはいっても信頼 性の低い史料や事象も見たいというユーザがいるであろ うことに対応するためである，標準モードでは，事象等 級 1 の事象のみを表示する. エキスパートモードでは, 事象等級 2 の事象 (および等級 C と E の史料) も表示す る、エキスパートモードを選択すると，「ここから先は, 等級 C と $\mathrm{E}$ の史料を見たい方のために特別に用意した モードです。等級 C と E の史料は信頼性が不確実であ ることと，それにもとづく事象の実在性も不確実である ことに，十分注意してください」という警告ウィンドウ が現われる。

史料本文の閲覧には，事象番号をクリックするか, 複 数事象を選択して「史料本文表示」ボタンを押す。する と一つの別ウィンドウが現われて, 選択した全事象の詳 細（事象番号・事象等級・種別・事象日・綱文全文・史

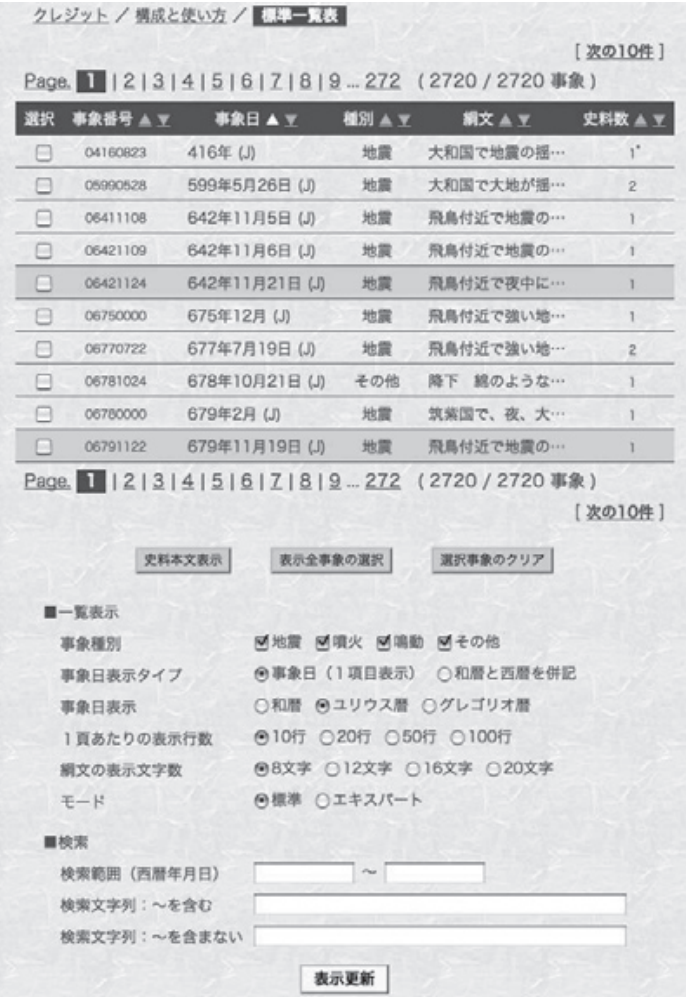

Fig. 3. First page of the event table of the Online Database of Historical Documents on Japanese Earthquakes and Eruptions in the Ancient and Medieval Ages.

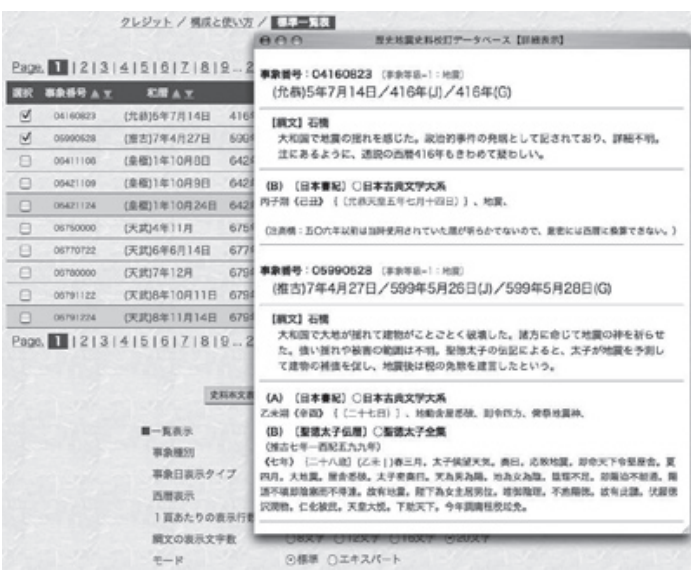

Fig. 4. A page showing full-texts of historical documents of the checked earthquakes on the Online Database of Historical Documents on Japanese Earthquakes and Eruptions in the Ancient and Medieval Ages.

料全文) が一連で表示される (Fig. 4). 前述のように, 標 準モードでは史料等級が A と B の史料のみ，すなわち 歴史学によって史料と認められるレベルのものだけが精 
選されて示される.エキスパートモードでは史料等級 $\mathrm{C}$ と Eの史料も表示される. 等級 Dのものは本データベー スでは一切表示されない. 出力形式は HTML か XML かが選択できる.

検索は一覧表の画面でおこなう。一覧表に抽出したい 事象を西暦年月日の範囲で指定することと，任意の文字 列を含む事象を抽出することができる，史料本文は，抽 出されたのちに詳細表示で見ることになる，文字列によ る検索は, 複数の文字列の or 検索, and 検索, およびそ れらの組み合わせが可能である。西暦年月日による検 索に関しては, 早川・小山（1997）と小山・早川（1998） の提案に従って, 1582 年 10 月 15 日以前はユリウス暦 でおこなうようになっている，なお，武者史料の西暦年 月日にはかなりの誤りがある（そもそも，1582 年までは ユリウス暦, 1583 年以後はグレゴリオ暦と例言に書い てあるにもかかわらず，すべてグレゴリオ暦になってい る). そこで, 本プロジェクトで新たに開発したソフト ウェア『換暦』を用いてすべての和暦を西暦に自動変換 した（もちろん，和暦そのものをまず校訂した）[早川・ 他 (2005)]. 一覧表示では, 年代にかかわらずュリウス 暦とグレゴリオ暦のどちらでも選べる.

データベースの仕上げが近くなった段階で, 公開後の メンテナンス（誤りの修正, さらなる史料校訂, 新史料 の追加など）を考慮し，また最終段階の作業を能率化す るために, データベースに編集モードを付加した。これ により, 専用サーバに置かれた XML データにパスワー ド認証で入って, 随時更新することが可能となった，更 新履歴は保存され, 編集者は閲覧もできる.

\section{4 いくつかの問題}

史料には異名同書が少なくない[例えば，田良島 (2007)］。地震史料集では, 一例として『異本塔寺長帳』 『塔寺八幡宮略記長帳』『塔寺八幡宮長帳続』『異本塔寺長 帳原題長帳続年日記』がある．また『愚管記』と『後深心 院関白記』, 『尚通公記』と『後法成寺関白記』なども同様 で, これらは複数の刊本の間でも(つまり歴史学者の間 でも) 名称が互いに異なっている。これは, 日本史を専 門としない地震史料集利用者を混乱させる要因の一つ であったし，データベースにおいては検索に支障をきた す問題でもあるので，史料名の統一を図った，基本的な 方針は, 大学共同利用機関法人 - 人間文化研究機構 - 国 文学研究資料館の『日本古典籍総合目録』データベース （http://base1.nijl.ac.jp/ttkoten/about.html）に準拠し，そこに ないものは当該史料の刊本や翻刻者の命名を採用し，一 部は広く通用している史料名を用いるというものであ る.

本データベースのテキストで利用している文字セッ
トはShift-JIS であるが, 既刊地震史料集には多くの Shift-JIS 外の文字が含まれている。和暦年号と史料名は すべて新字に置き換えたが, 史料本文については, 原則 として校訂に用いた典拠に忠実に外字のままとした。 そ れらについては, 文字鏡研究会『今昔文字鏡』が定義し ている「文字鏡番号」をXML の実体参照形式で記述し, 検索結果は画像で表示するようにした。 この外字の問題 と, JIS 標準文字の範囲内でも「国」と「國」や「浅間」と 「淺間」を同義とするテーブルをまだ実装していないた めに, 文字列による検索には支障が残っており, 改善が 必要である。

史料本文は, 校訂に用いた刊本に忠実になっているた めに白文であるものが多い. 地震研究者や防災関係者が 便利に使えるためには現代語訳を付ける必要があるが, 研究期間中には不可能であった。 これも今後の大きな課 題である. また，ウィキ（Wiki）システムを用いて史料 解題データベースを作りつつあり, 将来は史料名から参 照できるようにする予定だが, 現在はまだリンクされて いない.

データベースの公開は静岡大学防災総合センターを 通じて既になされている予定だったが, 現在まだ調整中 で遅れている。この論文が印刷される頃には公開されて いるはずだが，画面のデザイン等に多少の改良が加えら れる可能性がある. 科研費終了後も, メンバーが「古代 中世地震史料研究会」というグループを作っていて, 以 上のような不備の改善や, $\mathrm{E}$ 級史料の検討を続け, デー タベースの維持管理に当たっている.

\section{§5. おわりに}

日本の歴史地震研究のさらなる発展のためには, 基盤 整備として地震史料の全文データベースの構築が必要不 可欠であることを述べて, 唯一作られたばかりの「古代 中世地震噴火史料データベース」を概観した。

しかし, 既刊の地震史料は近世（江戸時代）のものが 圧倒的に多く, しかも時代が下るにつれて「観測密度」 が非常に高くなるので, 地震学の最新知見によって見直 す価值のきわめて高い宝の山であり，これをこそデータ ベース化することが強く望まれる. 地震研究者・防災関 係者によって近世地震史料が存分に活用されれば, 地震 活動論・震源過程論・長期評価・地震災害軽減などにいっ そう大きなフィードバックが得られるであろう。

そのための方法論と具体的手法は, 前章で紹介したも のが基本的に適用できると考えられる，ただし，古代・ 中世に較べて史料の構造が複雑なものが多く（とくに新 収史料), またローカルな史料が膨大なので, ある程度の 信頼性を確保したXML データを準備するのが非常に大 
変だと思われる，全国レベルの組織的な共同事業を構築 して，長期的な国家プロジェクトとして取り組む必要が ある.しかし, 統一的な仕様に沿って, 地震や地域を限っ て少しずつでも史料データベースを増やしていくことは 有効であろう。例えば松浦・他 (2003) は, 1847 年善光 寺地震の史料を XML に対応することを念頭に置いて電 子化したというから，そのようなデータがどの程度の加 工で前章のデータベースに組み込めるかどうか, 検討し てみる価值があるのではなかろうか.

なお, 前章で紹介した最初の研究課題では, ヨーロッ パで開発されて国際的に普及しつつある震度データ点 （IDP; Intensity Data Point）データベース［例えば，佐竹 (2005)］と互換的な震度データベースもテーマの一つで あった。しかし，ある程度の検討はおこなったものの[例 えば, 原 (2005)], 構築するには至らなかった。何らか の形の震度データベースは, 日本でも作っているグルー プがあると思われるが, 歴史地震関係のデータベースと して重要なものである（もちろん最近の地震まで含むの が望ましいが). GIS の最新の技術を使った検討が続け られており [例えば, 原・柴山 (2007), 原 (2008)], 近い 将来に大きな成果が出ると期待される.

\section{謝辞}

本稿で紹介した科学研究費補助金研究課題の研究分 担者・研究協力者であった小山真人・佐竹健治・都司嘉 宣・早川由紀夫・榎原雅治・笹本正治・高橋昌明・田良 島哲・藤田明良・矢田俊文・原正一郎・安永尚志・前嶋 美紀の諸氏に感謝するとともに，有益なご助言を頂いた 2 名の査読者にお礼を申し上げます，編集担当の松浦律 子氏にもお世話になりました。

\section{文献}

原正一郎, 2005, 地震史料の XML データ作成, 月刊地球, 27, 853-860.

原正一郎, 2008, 空間に基づいた情報解析ツール, アジア 遊学, No.113, 128-135.

原正一郎・柴山 守, 2007 , 地域情報学の構築と時空間情 報解析ッール, 人文科学とコンピュータシンポジウム 論文集, Vol.2007, No.15, 71-78.

早川由紀夫 - 小山真人, 1997, 1582 年以前の火山噴火の 日付をいかに記述するか一グレゴリオ暦かユリウス 暦か?,地学雑誌, 106, 102-104.

早川由紀夫・小山真人・前嶋美紀, 2005 , 史料に書かれた 日付の西暦換算と表記法, 月刊地球, 27, 848-852.

石橋克彦 1983,1433 (永享 5) 年会津地震 (M6.7) の非実 在性, 地震 2,36, 169-176.

石橋克彦, 1985, 歴史地震研究で感じたこと (要旨), 歴 史 地 震，第 1 号, 55-58.<http://historical.seismology.jp/ ishibashi/feeling.html>, (参照 2009-4-21).

石橋克彦, 1987, 地震予知研究における歴史地震研究の現 状と問題点, 地震予知研究シンポジウム (1987), 129142 .

石橋克彦, 1995, 古地震研究の問題点, 太田陽子・島崎邦 彦(編)「古地震を探る」, 古今書院, 193-207.

石橋克彦, 1997, 江戸時代の首都圏直下型被害地震の見直 し 2.1670 （寛文 10）年の幻の相模地震について, 地震 2, 50, 345-347.

石橋克彦, 1998, 実在しない天福元年二月五日 (ユリウス 暦 1233 年 3 月 17 日) の南海巨大地震, 地震 $2,51,335-$ 338.

石橋克彦, $2005 \mathrm{a}$, 地震史料のデータベース化, 2003 年度 総合研究大学院大学共同研究プロジェクト「文化科 学研究分野における情報資源共有化のためのコラボ レーション研究」第 1 回研究集会報告書, 5-22.

石橋克彦, $2005 \mathrm{~b}$, 日本の古代・中世の地震史料の校訂と データベース化, 月刊地球, 27, 811-818.

石橋克彦 - 小山真人 - 佐竹健治・都司嘉宣 - 早川由紀夫 · 榎原雅治・笹本正治・高橋昌明・田良島哲・藤田明良・ 矢田俊文・安永尚志 - 原正一郎, 2003, 古代 - 中世の日 本の全地震史料の校訂 - 電子化について, 日本地震学 会講演予稿集, 2003 年度秋季大会, C023.

石橋克彦・古代中世地震史料データベース化研究グルー プ, 2005 , 日本の古代・中世の地震史料の校訂とデータ ベース化, 地球惑星科学関連学会 2005 年合同大会予稿 集 (CD-ROM), J027-012.

石橋克彦・古代中世地震史料データベース化研究グルー プ, 2008, 「地震・噴火史料データベース（古代・中世編） 」のインターネット公開, 日本地球惑星科学連合 2008 年大会予稿集 (CD-ROM), S141-002.

Ishibashi, K., 2004, Status of historical seismology in Japan, Annals of Geophysics, 47, 339-368.

Ishibashi, K., M. Koyama, K. Satake, Y. Tsuji, Y. Hayakawa, M. Ebara, S. Sasamoto, M.Takahashi, S. Tarashima, A. Fujita, T. Yata, H. Yasunaga, S. Hara, and Y. Maejima, 2005, Emending and databasing all historical earthquake documents in the ancient and medieval ages in Japan, AOGS 2nd Annual Meeting 2005, 58-SE-A1478.

Ishibashi, K. and Research Group on Databasing Japanese Ancient and Medieval Historical Earthquake Documents, 2007, Emending and databasing all historical earthquake documents in the Japanese ancient and medieval ages through interdisciplinary collaboration, IUGG XXIV General Assembly, SW001-6491, <http://www.iugg2007perugia.it/ webbook/pdf/S.pdf>, (参照 2009-4-21).

岩崎伸一, 1988, 歴史地震史料集データベース化計画, 防 災科学技術, 62 号, 10-13。

岩崎伸一, 1999 , 歴史地震史料集電子データベースの現状 と課題, 地学雑誌, 108, 465-471.

岩崎伸一・吉井敏赾・都司嘉宣・石橋克彦・笠原敬司・ 小見波正隆, 1990, 歴史地震史料集のデータベース化, 地震学会講演予稿集, 1990 年度春季大会, 182.

小山真人, 1999 , 日本の史料地震学研究の問題点と展望一 次世代の地震史研究に向けて一, 地学雑誌, 108, 346369.

小山真人・早川由紀夫, 1998 , 歴史時代の地震 - 火山噴火 
の日付をいかに記述すべきか, 地球惑星科学関連学会 1998 年合同大会予稿集, 328.

前嶋美紀, 2004, 地震史料データベースの試作版と諸問 題, 史料地震学と地震危険度評価に関する日伊ワー クショップ予稿集, < http://historical.seismology.jp/erice/ archive/WS2004_abstract.pdf $>$, (参照 2009-4-21).

松浦律子 - 中村 操 - 茅野一郎 - 唐鎌郁夫, 2003, 震度分 布にもとづく江戸時代の 4 地震の震源域と規模の再検 討 (概報) : 1662 年日向灘・1769 年日向・豊後・1847 年善光寺地震・1861 年宮城の 4 地震について, 歴史地 震, 第 19 号, 53-61.

歴史地震研究会 (編), 1988 , 歴史地震史料のデータベー ス化に関する討論会, 歴史地震, 第 4 号, 179-197.

歴史地震史料データベース化委員会, 1989 a, 歴史地震史 料集データベース化について, 地震学会講演予稿集, 1989 年度春季大会, 225 .

歴史地震史料データベース化委員会, $1989 b$, 歴史地震史 料集のデータベース化について一パソコンで読める
史料集一, 歴史地震, 第 5 号, 151-155.

佐竹健治, 2005, イタリアの歴史地震研究の紹介 (2) 一イ タリアとヨーロッパの震度データ点データベース一, 月刊地球, $27,882-887$.

田良島哲, 2007, コンピュータ, ネットワークと歴史研 究—これまでとこれから一, 暦博, 第 140 号, 国立歴史 民俗博物館, 6-10.

宇佐美龍夫, 1995, 地震史料収集刊行の歩み, 太田陽子・ 島崎邦彦 (編)「古地震を探る」, 古今書院, 27-35.

宇佐美龍夫, 2003, 最新版日本被害地震総覧 [416] -2001, 東京大学出版会, 605 pp.

山本武夫・萩原尊禮, 1995, 正徳元年 (一七一一) 十一月 十一日讃岐高松地震一史料不吟味による誤認, 萩原尊 禮 (編)「古地震探求一海洋地震へのアプローチ」, 東京 大学出版会, 252-263.

山本武夫・松田時彦・萩原尊禮, 1989, 疑惑の諸地震, 萩 原尊禮 (編)「続・古地震一実像と虚像」, 東京大学出 版会, 215-266. 